\title{
COMPARATIVE IMMUNOTOXICOLOGY - A NEW DIRECTION
}

\author{
A. K. SIWICKI ${ }^{1.4}$, M. STUDNICKA ${ }^{2}$, M. MORAND ${ }^{3}$, F. POZET ${ }^{3}$, E. TERECH-MAJEWSKA ${ }^{4}$
}

${ }^{1}$ Department of Fish Pathology and Immunology IFI, Piaseczno, ${ }^{2}$ Department of Physiology and Toxicology, Catholic University Lublin, Poland, ${ }^{3}$ Laboratoire Departemental d'Analyses, Conseil General du Jura, Lons le Saunier, France, ${ }^{4}$ Department of Epizootiology with Clinic of Infections Diseases, Faculty of Veterinary Medicine, University in Olsztyn, Poland

Received July 22, 1998

Accepted September 21, 1998

\begin{abstract}
Siwicki A. K., M. Studnicka, M. Morand, F. Pozet, E. Terech-Majewska: Comparative Immmunotoxicology - a New Direction. Acta vet. Brno 1998, 67: 295-301.

Increasing concentrations of xenobiotics in the environment, food and water supplies has direct or non-direct effects on the immunocompetent cell activity, cellular and humoral defence mechanisms and protection from diseases in animals and human. At this moment we must develop comparative aspects of immunotoxicology, justifying the use of invertebrates, amphibians and especially fish and reptiles, as models. The defence mechanism indices have been used in various laboratory and field experiments to analyze the influence of xenobiotics on the defence mechanisms and disease resistance of mammals, birds, amphibians and fish. Many of the standard immunological techniques have been modified for optimal results. In this paper we present the basic immunological techniques for study of the effects of xenobiotics on the cellular and humoral defence mechanisms in fish.
\end{abstract}

Xenobiotics, fish, defence mechanisms

Understanding the human and animal health risk associated with environmental exposures involves defining the cascades of events between exposure to an environmental agent and the resulting effects on health. To cause health impairment, a pollutant must be absorbed into the body and result in biological change. For most environmental pollutants, little is known about the flow of events between exposure and health effect. Biological markers are powerful tools that can be used to address many different issues confronting environmental health scientists. Effects of markers are indicators of biological responses. They provide information concerning the likely health outcomes associated with different target doses of environmental pollutants or their metabolites. Overall, biological markers offer the possibility of using human data to make health risk assessment more meaningful, realistic and host-effective. Risk assessment attempts to determine the consequence of toxicant exposure at the human population level. Biomarkers are frequently used to assess the responses and effects of toxicants on laboratory animals. Therefore, there is a need to extrapolate from animal data to human health effects, not only because most of the uncertainties associated with human epidemiological studies. The immune and host defences are highly conserved across species such that immunocompetent cells and some products of the immune system in humans, mice, rats and also in teleost fish are similar. Also, in instances where controlled human studies have been possible, results of immune function studies have been accurate predictors of effects in humans (Hug gett et al. 1989).

Increasing concentrations of xenobiotics in the environment, industry, food and water

Address for correspondence:

A. K. Siwichi

Department of Fish Pathology

and Immunology IFI.

05-500 Piaseczno. Poland

Phone: $+\$ 8227562490$

Fax: +48227562490

E-mail: irs@warman.com.pl 
supplies, has become a problem of significant proportions; today, the danger is greater than ever before. Many environmental pollutants are toxic to animals and humans, resulting in overt clinical disease and even death. All of the pollutants have direct or indirect effects on the immunocompetent cells and nonspecific defence mechanisms. At this moment we must start open discussion about comparative aspects of immunotoxicology, justifying the use of invertebrates, amphibians and especially fish, and reptiles as animal models. First, they are numerous, highly visible and ubiquitous members of the biosphere, and we should understand how xenobiotics affect their immune systems. Second, they are important to essential food chains and are therefore potential candidates for vector of diseases. Third, they can be used as surrogates, sentinels, to ascertain the effects of immunotoxicants on humans for legal and ethical reasons. Surely, an appropriate animal, not necessarily a mammal, may be chosen since lower vertebrate animals (especially fish) possess immune systems that often mirror those of humans. Finally, by analyzing the effects of xenobiotics as potentially deleterious to the immune system of all organisms, the comparative approach can assume an evolutionary flavor that should be of deep concern for all of us. For the biological consequences of such pollution (as a source of environmental stress) may range beyond that which is immediately apparent. Nevertheless we must exert caution in extrapolating causes and effects from invertebrates and lower vertebrates to humans (Huggett et al. 1989; Vos 1977; Vos 1980).

A broad spectrum of chemicals alter immune functions allowing for the immune mechanisms potential as a target organ system for use in assessing the toxicity of exposure to chemicals. Because considerable information on the nonspecific defense mechanisms, cell-mediated immunity and molecular components of the immune system exists, immune responses are especially well suited for comparative analysis that emphasize mechanisms of toxicity. Cellular or subcellular and organismal immunological indicators of either exposure to or effects of chemicals can be used as assessment tools. Such immunological indicators fall within the category of measurement endpoints defined as biomarkers (Huggett et al. 1989).

The immune system is a highly evolved system that functions to provide organisms with ability to resist pathogenic agents, destroy neoplastic cells, and reject nonself components. The immune system has increased in complexity as animals have evolved. According to the present level of knowledge, differentiated lymphoid organs first appear in the fish, with an develop in structural definition through amphibians and reptiles to birds and mammals. Higher mammals possess five immunoglobulin classes, birds three, reptiles and amphibians two, and fish only one class. No immunoglobulins are found in invertebrates, but functionally analogous proteins, mostly agglutinins and inducible humoral factors (apidaecins and abaecins) are present (Glinski and Jarosz 1995a; Glinski and Jarosz 1995b). Although all vertebrate species synthesize immunoglobulins, selection of humoral immunoglobulin assays as biomarkers will be constrained by the sophistication of the immune system of the species under investigation. Similar assays have been developed in invertebrates using agglutinins.

Several aspects of defence mechanisms amenable for use as specific biomarkers are conserved phylogenetically. Phagocytosis and cell-mediated responses are very important part of immunological mechanisms and perform a key role in the regulation of immune response. Assays of these responses can provide useful measures of immunosuppression. The fundamental units of the defence mechanisms are the leukocytes, which develop from pluripotent stem cells and undergo differentiation, maturation, and proliferation into morphologically and functionally distinct cell population: polymorphonuclear (PMN) cells, MN phagocytes, and lymphocytes in higher vertebrates (Huggett et al. 1989).

Generally, defense mechanisms characterize two pathways: nonspecific immune 
responses mediated by $\mathrm{MN}$ phagocytes (blood monocytes, tissue macrophages) and granulocytes, which can recognize foreign material nonspecifically and specific immune responses mediated by several effector lymphocytes, which are directed and specific for an eliciting antigen.

The nonspecific defence mechanisms comprise two types of responses: phagocytosis and inflammation. The phagocytic and inflammatory responses can be enhanced by immunocompetent cell products (cytokines). Other important cells involved in immune surveillance in vertebrates are the natural killer (NK) cells. These cells can recognize changes in surface markers that occur on virally infected cells and on some tumour cells. They can be activated by cytokines such as IL- 2 .

The specific immune responses have two major components: cell-mediated immunity (CMI) and humoral-mediated immunity (HMI). The CMI response is characterized by the sensitization of $\mathrm{T}$-cells through antigen presentation and by the differentiation and proliferation of T-cells into effector, regulatory and memory cells. Sensitization is assisted by macrophages and other accessory cells that concentrate antigenic determinants on their surfaces for presentation to T-cells. Macrophages also provide soluble factors called cytokines (IL-1). Macrophages are necessary for T-cells to function, especially for T helper and $T$ suppressor cells $\left(T_{h}, T_{s}\right)$. Memory cells are produced for each T-cell type and are stimulated by antigen. The HMI response is characterized by production of antibody molecules that react specifically with antigen. Mammals possess five Ig classes, birds three, reptiles and amphibians two, and fish only one class. The major role of antibodies is to protect the host from infectious disease and can involve the following functions: opsonization, complement-mediated lysis, antibody-dependent cell cytotoxicity (ADCC) and virus neutralization.

The defence mechanism parameters have been used in various laboratory and field experiments to analyze the influences of xenobiotics on the nonspecific cellular and humoral defence mechanisms, specific immune responses and disease resistance of mammals, birds, amphibians and fish. In the following examples, immune assays are broadly grouped according to the specificity of responses. Some nonspecific assays such as the determination of lysozyme, C-reactive protein (CRP) or complement levels have been used extensively in the past for analyzing the effects of environmental contamination on the health of fish, birds and mammals. Lysozyme and CRP are important in the initial destruction of invasive agents and in some cases can serve as an early biomarker indicating deterioration of some protective mechanisms (Blaxhall 1972; Rice 1986; Siwicki and Studnicka 1987). Phagocytosis is an important parameter of nonspecific defense mechanisms as it is well conserved throughout phylogeny and important in immune surveillance in vertebrates as well as invertebrates. Therefore, assays of phagocytosis and intracellular killing activity have potential as bioindicators of environmental contamination among several animal phyla (Jabs et al. 1980; Rook et al. 1985). Also macrophage functions have been proposed as sensitive indicators for the effects of xenobiotics present in the aquatic environment (Dunier and Siwicki 1994; Subasinghe and Arthur 1990; Zeeman and Brindley 1981).

The humoral-mediated immunity (HMI) assays have been used in many studies to determine altered immune capacity which is caused by xenobiotics. Various laboratories demonstrated immunosuppression of humoral antibody levels in fish and birds exposed to heavy metals. A reduction in antibody-secreting cells following bath immunization was observed in fish that had been exposed to phenol, formalin, detergent solutions and antibiotics (Siwicki et al. 1993). HMI has also been evaluated in chickens and fish following exposure to pentachlorophenol (PCP), polychlorinated biphenyl (PCB) and pesticides (Dunier and Siwicki 1994). 
The scientific community should adopt an integrated ecological approach to risk analysis that identifies direct and indirect health risk of human activities ranging from chemical contaminants development practices (Epstein 1995).

Several immunotoxicological laboratories have organized immunological assays applicable to several classes of animals. Zeeman and Brindley (1981) and Siwicki and Anderson (1993) previously presented the protocols and the immunological assays applicable to control the influence of xenobiotics on the nonspecific cellular and humoral defence mechanisms in fish.

In this paper we present the rationale for development of biomarkers of fish host defence mechanisms as targets for study immunotoxicity of xenobiotics and discuss them in terms of sensitivity to toxicants known to affect high vertebrate immunity.

\section{Simplified assays for study nonspecific defence mechanisms in fish}

In presenting the following assays, we discuss some of the advantages and disadvantages of each. Without a doubt, as biologists, pathologists, comparative immunologists, and research personnel work with assays, new and better modifications will be found to make the tests more reliable and easier to do. We hope the following protocols can be benefit for control effects of pollutants or xenobiotics on defence mechanisms in fish.

\section{Leukocrit samples assay}

The percent volume of leukocytes in blood gives clues to the health of the animal, and can be helpful in determining abnormalities arising from polluted aquatic environments. The leukocrit levels in normal fish are usually between 1-2\%. In our experience, this assay is not very dependable and often does not correlate well with the leukocyte counts by hemocytometer. In some cases the top of the haematocrit (RBC) pack is difficult to distinguish from the infiltrating leukocytes (Blaxhall 1972; Hesser 1970).

\section{Adherence/NBT assay}

Adherence to glass is an important early indicator of activated neutrophils and monocytes. The following assay is designed to show that activation in addition to the increases in oxygen radical products. Activated neutrophils should adhere to glass and show a segmented nucleus. A blue-staining halo will surround the cell. We usually count 2 of the most dense fields at $400 \times$ magnification. An unstimulated animal may give about $20-40$ cells per field; a strongly stimulated one 200-400, and a suppressed animal only 5-10 cells (A nderson 1992; Anderson et al. 1992; Siwicki and Anderson 1993).

\section{Phagocytic activity of PMN cells by spectrophotometric assay}

These simple and rapid spectrophotometric assay should be quite adaptable for general field use. The NBT is reduced to formazan in the reaction with the oxygen radicals from neutrophils and can be analyzed by spectrophotometer. This assay is particularly helpful when many fish are sampled (Anderson 1992; Siwicki et al. 1985; Siwicki 1989; Siwicki et al. 1993).

\section{Respiratory burst activity assay}

Phagocytes possess a unique membrane enzyme, NADPH oxidase, capable of the one electron reduction of molecular oxygen into superoxide anion $\left(\mathrm{O}_{2-}\right)$ during a process named the respiratory burst. The reducing equivalents are provided by NADPH, which is generated via the hexose monophosphate (HMP) shunt, and are independent of the mitochondrial cytochrome system. Following membrane stimulation, as occurs when a particle adheres to the phagocyte, both the respiratory burst and HMP shunt are activated 
and these two processes are generally agreed to be linked together. Most of the $\mathrm{O}_{2}$. produced is dismutated to $\mathrm{H}_{2} \mathrm{O}_{2}$, and this occurrence either spontaneously or catalyzed by the enzyme superoxide dismutase (SOD). The two main methods used to measure this processes are: the reduction of ferricytochrome $\mathrm{C}$ and the reduction of the redox dye nitroblue tetrazolium (NBT). The first method detects extracellular $\mathrm{O} 2$ whereas the second detects intracellular $\mathrm{O}_{2 .}$. Before the respiratory burst will occur the macrophage and neutrophil surface membrane must be stimulated. This can be achieved with particulate stimuli such as bacteria, zymosan or phorbol myristate acetate (PMA) (Jabs et al. 1980; Rook et al. 1985; Siwicki and Anderson 1993). In our study, we used NBT reduction assay for the study of respiratory burst activity of phagocytes stimulated by PMA.

\section{Potential killing activity of phagocytic cells assay}

Fish phagocytic cells (neutrophils, monocytes/macrophages) have a vital role in many aspects of the nonspecific defence mechanisms and specific immune response. As well as being accessory cells important in initiating immune responses they are also potent effector cells capable of killing a wide range of pathogens. The following methods were used for analysis of blood neutrophils and monocytes/macrophages killing activity ( $\mathrm{Jabs}$ et al. 1980; Rook et al. 1985; Siwicki and Anderson 1993).

\section{Myeloperoxidase (MPO) activity assay}

MPO is a very important intracellular enzyme that participates in intracellular killing of pathogens. The production of myeloperoxidase in neutrophils is detected by overlays of substrates. Those cells having the MPO will appear as having dark granules. The total activity of MPO activity in peripheral blood granulocytes should range between 95-110 points in normal animals and in polluted aquatic environments this value may be reduced to 50-70 points (Sigma Chemical Company 1991; Siwicki 1989; Siwicki and Anderson 1993).

\section{Lysozyme activity assay in serum and organs}

Lysozyme is an important enzyme in blood involved in active lysis of bacteria. This enzyme attacks specifically structures containing muramic acid and has also been reported to have antiviral and antiparasitic properties. The presented assay is based upon the lysis of the lysozyme-sensitive Gram-positive bacterium, Micrococcus lysodeikticus, which is obtained freeze-dried from major chemical suppliers. Lysis can be measured either turbidimetrically or in agarose plates. For convenience, accuracy and sensitivity of the turbidimetric assay is preferable in comparative immunotoxicology (Siwicki and Studnicka 1987; Siwicki et al. 1993).

\section{Ceruloplasmin and CRP activity assay in serum}

Ceruloplasmin is a blue alpha-2-globulin and C-reactive protein are enzymes of "acutephase protein". The acute phase response is the reaction of the animal to disturbances in its homeostasis caused by infection, tissue injury, neoplastic growth or immunological disorders. These responses are in turn associated with production of cytokines and other immunological mediators. The mediators activate receptors on different target cells leading to a systemic reaction. Many quantitative methods for ceruloplasmin and CRP in plasma or serum have been proposed. The ceruloplasmin (p-phenylenediamine: PPD oxidase) assay procedure described herein has been so evaluated, and a very strong positive linear correlation between the total copper content standard serum and the PPD oxidase activity exist (Rice 1986). 
Total protein and immunoglobulin (Ig) levels assay in serum

The study of fish immunoglobulin has provided the foundation of numerous investigations involving the phylogeny and ontogeny of the fish immune system and detailed characterization of the fish immune response. More recently, fish immunoglobulin has been used in assessing the specificity of the immune response in disease resistance, studying the mechanisms of antigen uptake and processing and evaluating the effects of toxicants and immunomodulators on the humoral immune response. Isolation and characterization of immunoglobulin from fish has been the subject of a number of investigations. A variety of techniques for separation and purification of fish immunoglobulin have been used and have included precipitation in saturated ammonium sulfate, separation by molecular sieving, and ion exchange chromatography. All applied techniques for classification of the class of immunoglobulin showed that in fish only one class, IgM exists.

The technique described here utilizes a spectrophotometric technique previously developed for the study of total immunoglobulin levels in serum or plasma. Analysis of total Ig level in plasma is based on the biuret colorimetric method. However, by following methods, first the immunoglobulins are separated from plasma by precipitation with polyethylenic glycol 10,000 (Sigma) and remaining supernatant is read. That number is subtracted from the total protein to give total immunoglobulin. Protein readings from supernatant will give the amount of protein taken out by absorption to polyethylene glycol. To calculate total immunoglobulin, subtract these readings from total protein on individual samples. Compare with standards for calculation of protein (Siwicki and Anderson 1993; Siwicki et al. 1993; Siwicki et al. 1994).

\section{Other methods}

Other techniques for analyzing the effects of xenobiotics on the defence mechanism were used in our immunotoxicological study: ELISPOT assay for quantification of antibody secreting cells and lymphocyte proliferation (LP) assay for study the lymphocyte activity (Siwicki and Dunier 1990; Siwicki and Dunier 1993; Siwicki et al. 1993). In our experimental study, we observed that xenobiotics and other aquatic pollutants increased the lymphocyte $\mathrm{T}$ and lymphocyte $\mathrm{B}$ activity, and the antibody secreting cells levels in fish (Dunier and Siwicki 1994).

\section{Nové směry ve srovnávací imunotoxikologii}

Zvýšené koncentrace xenobiotik v prostředí, potravě i vodě mají přímý i nepřímý vliv na aktivitu imunokompetentních buněk, buněčné a humorální obranné mechanismy a odolnost proti nemocem u zvírat i lidí. Proto je nutné rozvíjet srovnávací aspekty imunotoxikologie při využití bezobratlých, obojživelníků i plazů jako modelů. Parametry obranných mechanismů mohou být využity při různých laboratorních i terénních experimentech $\mathrm{k}$ analýze vlivu xenobiotik na obranné mechanismy a odolnost vůči nemocem u savců, ptáků, obojživelníků a u ryb. Řada standardních imunologických technik (metod) byla modifikována pro dosažení optimálních výsledků. $\mathrm{V}$ předkládané práci jsou prezentovány základní imunologické techniky a metody pro studium působení xenobiotik na buněčné a humorální obranné mechanismy u ryb.

\section{References}

ANDERSON, D. P. 1992: In vitro immunization of spleen sections and NBT, phagocytic, PFC and antibody assays for monitoring the immune response. FITC. SOS Publication. Fair Haven NJ, 2: 79-87 
ANDERSON, D. P., MORITOMO, T., GROOTH, R. 1992: Neutrophil, glass-adherent. nitroblue tetrazolium assay gives early indication of immunization effectiveness in rainbow trout. Vet. Immunol. Immunopathol. 30: 419429

BLAXHALL, P. C.1972.: The hematological assessment of the health of freshwater fish. A review of selected literature. J. Fish Biol. 4: 593-604

DUNIER, M., SIWICKI, A. K. 1994: Effects of environmental contaminants and chemotherapeutics on fish defense

mechanisms. Arch. Pol. Fish. 2: 21-54

EPSTEIN, P. R. 1995: Reform Bill „Dead Wrong“" on Risk; Integrated Analysis Needed: Expert. Environ. Health Letter, 34, 14: 118

GLINSKI, Z., JAROSZ, J. 1995a: Cellular and humoral defences in honeybees. Bee World 76: 195-205

GLINSKI.Z., JAROSZ. J. 1995b: The role of apidaecins in antibacterial responses of the honeibees, Apis mellifera L.. Honeybee Sciences 16: 105-110

HESSER. E. F. 1970: Methodes for routine fish hematology. The progress. fish-cultur. 22: 164-171

HUGGETT, R. J., KIMERIE, R. A., MEHRIE, P. M., BERGMAN, H. L. 1989: Biomarkers: Biochemical, Physiological, and Histological Markers of Anthropogenic Stress. Lewis Publishers London, $250 \mathrm{p}$.

JABS, D. M., REGAN, M., HORITA, M., YOKOYAMA, M., TSENG, C. H. 1980: Assaying of human neutrophil function. Laboratory Management 18: 37-41

RICE. E. W. 1986: Ceruloplasmine assay in serum: standardization of ceruloplasmin activity in terms of international enzyme units. Diagnostic Laboratory 12: 39-53

ROOK, G. A., STEELE, J., UMAR, S., DOCKRELL, H. M. 1985: A simple method for the solubilisation of reduced NBT and its use as a colorimetric assay for activation of human macrophages by gamma-interferon. J. Immunol. Methods 82: 161-167

Sigma Chemical Company 1991: Leukocyte myeloperoxidase histochemical demonstration (Procedure No. 390), St. Louis, MO, $6 \mathrm{p}$.

SIWICKI, A. K. 1989: Immunostimulating influence of levamisole on nonspecific immunity in carp (Cyprinus carpio). Develop. Comparat. Immunol. 13: 87-91

SIWICKI, A. K., ANDERSON, D. P. 1993 : Immunostimulation in Fish: Measuring the Effects of Stimulants by Serological and Immunological Methods. U.S. Fish and Wildlife Service, IFI, Poland 1, 24 p.

SIWICKI. A. K., ANDERSON, D. P., WALUGA, J. 1993: Fish Diseases Diagnosis and Preventions Methods. FAO-Project, IRS Olsztyn Poland, $181 \mathrm{p}$.

SIWICKI, A. K., ANDERSON. D. P., RUMSEY, L. G. 1994: Dietary intake of immunostimulants by rainbow trout affects non-specific immunity and protection against furunculosis. Vet. Immunol. Immunopathol. 41: 125-139

SIWICKI, A. K.. COSSARINI-DUNIER, M. 1990: Effect of levamisole on the lymphocyte and macrophage activity in carp (Cyprinus carpio). Ann. Rech. Vet. 21: 95-100

SIWICKI, A. K.. DUNIER, M. 1993: Quantification of antibody secreting cells to Yersinia ruckeri by ELISPOT assay after in vivo and in vitro immunization of rainbow trout (Oncorhynchus mykiss). Vet. Immunol. Immunopathol. 37: 73-80

SIWICKI, A. K., STUDNICKA, M. 1987: The phagocytic ability of neutrophils and serum lysozyme activity in experimentally infected carp (Cyprinus carpio). J. Fish Biol. 31: 57-60.

SIWICKI, A. K., STUDNICKA, M., RYKA, B. 1985: Phagocytic ability of neutrophils in carp. Bamidgeh 37: 123128

SUBASINGHE, J., ARTHUR, R. 1990: Diseases of Asian Aquaculture. Asian Fisheries Society, Manilla Filippines 11: 26-29

VOS, J. G. 1977: Immune suppression as related to toxicology. CRC Crit. Rev. Toxicol. 5: 67-101

VOS. J. G. 1980: Immunotoxicity assessment: Screening and function studies. Arch. Appl. Toxicol. 4: 95-108

ZEEMAN. M. G.. BRINDLEY. W. A. 1981: Effects of toxic agents upon fish immune systems: a review. Immunologic Consideration in Toxicology. CRC Press, Florida, $47 \mathrm{p}$. 